\title{
PENINGKATAN KEAMANAN PANGAN DALAM PROSES PRODUKSI KERIPIK SINGKONG PEDAS
}

\author{
Mardiana ${ }^{1}$, Intan $Z^{2}$
}

\begin{abstract}
ABSTRAK
Makanan khas Indonesia yang akrab dengan masyarakat adalah keripik singkong. Pengolahan yang berbeda akan mnambah kualitas rasa. Industri rumah tangga keripik singkong pedas 99 merupakan salah satu industri yang menggunakan bumbu alami tanpa bahan pengawet maupun penguat rasa. Pengolahan masih bersifat tradisional jika dilihat dari alat-alat yang digunakan. Saat ini pemasaran masih terbatas pada kantin-kantin rumah sakit, perusahaan, instansi pemerintah, perguruan tinggi dan sekolah. Keripik singkong pedas 99 banyak digemari oleh konsumen tetapnya karena rasa pedas asli yang khas dari cabai. Para pelanggannya berkomentar "sulit berhenti jika sudah mengkonsumsi keripik singkong pedas 99”.

Kegiatan yang dilakukan dalam kegiatan pengabdian ini adalah 1) pelatihan keamanan pangan bagi industri rumah tangga, 2) pelatihan manajemen Usaha, 3) demonstrasi pembuatan keripik singkong pedas sesuai standar resep, tangga, 4) pembuatan meja yang ergonomis
\end{abstract}

Kata Kunci : keripik singkong pedas ; pelatihan ; buku saku keamanan pangan

\begin{abstract}
Indonesian food that people are familiar with cassava chips. Different processing will mnambah quality taste. Domestic industry spicy cassava chips 99 is one of the industries that use natural ingredients without preservatives or flavor enhancers. Processing is still traditional when viewed from the tools used. Nowadays marketing is still limited to the canteens hospitals, corporations, government agencies, colleges and schools. 99 spicy cassava chips favored by consumers because of their fixed original distinctive spicy flavor of chili. The customer commented "hard stop if already consume spicy cassava chips 99".

Activities undertaken in service activities are 1) training of food security for domestic industry, 2) management training efforts, 3) demonstration of making cassava chips and spicy as per standard recipes, 4) the making pocketbooks food security for domestic industry, 5) manufacture table ergonomic.
\end{abstract}

Keywords: spicy cassava chips; training; food safety pocket book

\section{PENDAHULUAN}

\footnotetext{
${ }^{1}$ Jurusan Ilmu Kesehatan Universitas Negeri Semarang

${ }^{2}$ Jurusan Ilmu Kesehatan Universitas Negeri Semarang
} 
Makanan merupakan kebutuhan pokok yang dikonsumsi sehari-hari oleh makhluk hidup termasuk manusia. Tanpa makanan seseorang tidak dapat bertahan hidup. Tetapi makanan memerlukan pengolahan yang baik dan benar agar dapat dimanfaatkan oleh tubuh. Dalam upaya penganekaragaman pangan untuk mengatasi kerawanan pangan perlu dilakukan identifikasi bahan makanan lokal yang berpotensi untuk dikembangkan. Salah satu makanan yang akrab dengan masyarakat Indonesia adalah singkong. Secara tradisional, singkong banyak diminati sebagai makanan pengganti beras karena singkong merupakan bahan makanan sumber energi yang digunakan tubuh untuk beraktivitas. Dalam perkembangannya saat ini singkong dimanfaatkan untuk berbagai makanan, penganan dan diambil patinya.

Salah satu jenis penganan yang banyak diminati adalah keripik singkong. Keripik singkong merupakan produk makanan ringan yang renyah dan harga relatif murah sehingga produk tersebut menjadi alternatif cemilan yang tepat untuk menemani waktu santai maupun disela-sela waktu bekerja. Saat ini keripik singkong mulai diinovasikan dalam berbagai rasa seperti keju, barbeque, asin manis, dan pedas Tetapi rasa asli bumbu pencampur keripik sudah jarang ditemukan. Ada beberapa hal yang perlu diperhatikan dalam pengembangan produk makanan tradisional seperti teknologi yang digunakan, manajemen usaha dan pemasaran, sarana dan prasarana yang dibutuhkan dalam pengolahan. Seperti kasus di Afrika Barat, walaupun mereka mengalami kemajuan kecil dalam mengolah beberapa makanan tradisional, akan tetapi pertumbuhan dan pengembangan industri kecil makanan menjadi terhambat oleh teknologi yang tidak efisien, manajemen yang buruk, modal kerja yang tidak memadai, akses terbatas pada bank dan lembaga keuangan lainnya, tingkat bunga yang tinggi dan margin keuntungan yang rendah (Aworh, 2008).

Menurut Winarno (1993) menyatakan bahwa sanitasi pangan erat kaitannya dengan kebesihan dalam tahap persiapan, pengolahan, penyimpanan serta penyajian makanan. Penyediaan air bersih dan aman, pemilihan bahan-bahan mentah yang bermutu tinggi dan penanganan yang higiene selama tahap persiapan dan tahap penyajian. Selain itu seluruh peralatan yang akan digunakan dan bersnetuhan dengan bahan pangan harus dijaga agar selalu dalam kondisi bersih dengan lingkungan kerja yang bersih.

Industri rumah tangga keripik singkong pedas 99 merupakan salah satu industri yang menggunakan bumbu alami tanpa bahan pengawet maupun penguat rasa. Pengolahan masih bersifat tradisional jika dilihat dari alat-alat yang digunakan. Saat ini pemasaran masih terbatas pada kantin-kantin rumah sakit, perusahaan, instansi pemerintah, perguruan tinggi dan sekolah. Keripik singkong pedas 99 banyak digemari oleh konsumen tetapnya karena rasa pedas asli yang khas dari cabai. Para pelanggannya berkomentar "sulit berhenti" jika sudah mengkonsumsi keripik singkong pedas 99”.

Dalam pengolahannya masih terdapat permasalahan diantaranya meja produksi yang tidak ergonomis sehingga pekerja seringkali mengeluh pegal di bagian tangan dan punggung karena posisi yang terlalu memaksakan terutama pada saat mengaduk bumbu dan keripik singkong, ruang pengolahan belum 
dilengkapi exhaust sehingga ketika berada disana sebenatar saja sudah terasa panas dan berkeringat. Pengolahan yang tidak higienis. Hal ini dapat terlihat ketika melakukan pengepakan pekerja hanya menggunakan tangan telanjang untuk memasukkan ke dalam plastik pengemas. Kondisi seperti memungkinkan terjadi kontaminasi antara pekerja dan produk. Selain itu, bahan pengemas tidak sesuai dengan jenis produk yang dihasilkan. Keripik singkong pedas 99 termasuk penganan semi basah.

\section{METODE PEMECAHAN MASALAH}

Metode pemecahan masalah dalam pengabdian ini adalah 1) Pelatihan keamanan pangan bagi industri rumah tangga, 2) Pelatihan manajemen Usaha, 3) Demonstrasi pembuatan keripik singkong pedas sesuai standar resep, 4) Pembuatan Meja yang ergonomis

\section{HASIL DAN PEMBAHASAN}

\subsection{Pelatihan Keamanan Pangan}

Pelatihan keamanan pangan dilaksanakan pada tanggal 21 agustus 2016. Dihadiri oleh 10 orang. Materi yang diberikan diantaranya kontaminasi silang peralatan, manusia dan bahan yang digunakan dalam proses produksi. Selain itu diberikan pula tentang bahan tambahan pangan yang diperbolehkan dan dilarang penggunaannya. Pada pelatihan ini juga pengabdi dan pengelola keripik pedas 99 melakukan uji fisik terhadap produk keripik pedas. Hasil yang diperoleh selama 2 minggu pengamatan terjadi perubahan rasa, aroma dan tekstur pada minggu ke-2 setelah keripik dikemas. Hal ini dikarenakan keripik singkong pedas termasuk produk semi basah sehingga masa simpan tidak panjang.

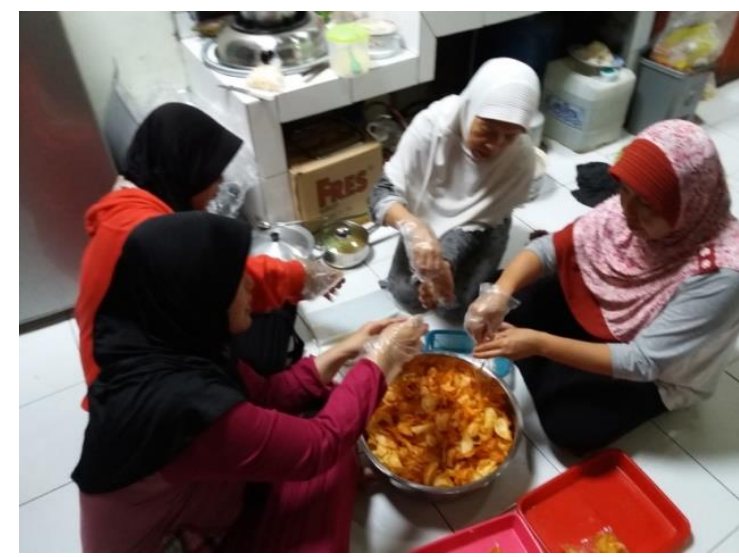

Gambar 1. Perubahan perilaku dalam Pengemasan pangan

\subsection{Pelatihan Manajemen Usaha}

Pelatihan manajemen usaha dilaksanakan tanggal 14 agustus 2016. Dalam manajemen usaha yang perlu diperhatikan adalah strategi pemasaran, pengelolaan usaha kecil. Selain itu, pemilik pekerjaan diberikan tips sukses dalam menjalani 
usaha. Dalam pelatihan ini pihak pengelola diberikan buku manajemen usaha kecil.

\subsection{Demontrasi Pembuatan Keripik Singkong Sesuai Resep}

Demonstrasi pembuatan keripik sesuai standar resep dilaksanakan pada tanggal 4 september 2016. Dihadiri oleh 10 orang. Dalam kegiatan ini pengabdi mempraktekkan cara pengolahan sesuai resep yang telah dibuat.Kegiatan ini diharapkan dapat meningkatkan rasa dari keripik singkong pedas tersebut. Selain pembuatan keripik singkong sesuai standar resep, dilakukan uji daya terima pada responden remaja. Hasil yang diperoleh $90 \%$ menyatakan suka terhadap keripik singkong. Rasa pedas sudah cukup, dan aroma khas cabai juga cukup tercium.
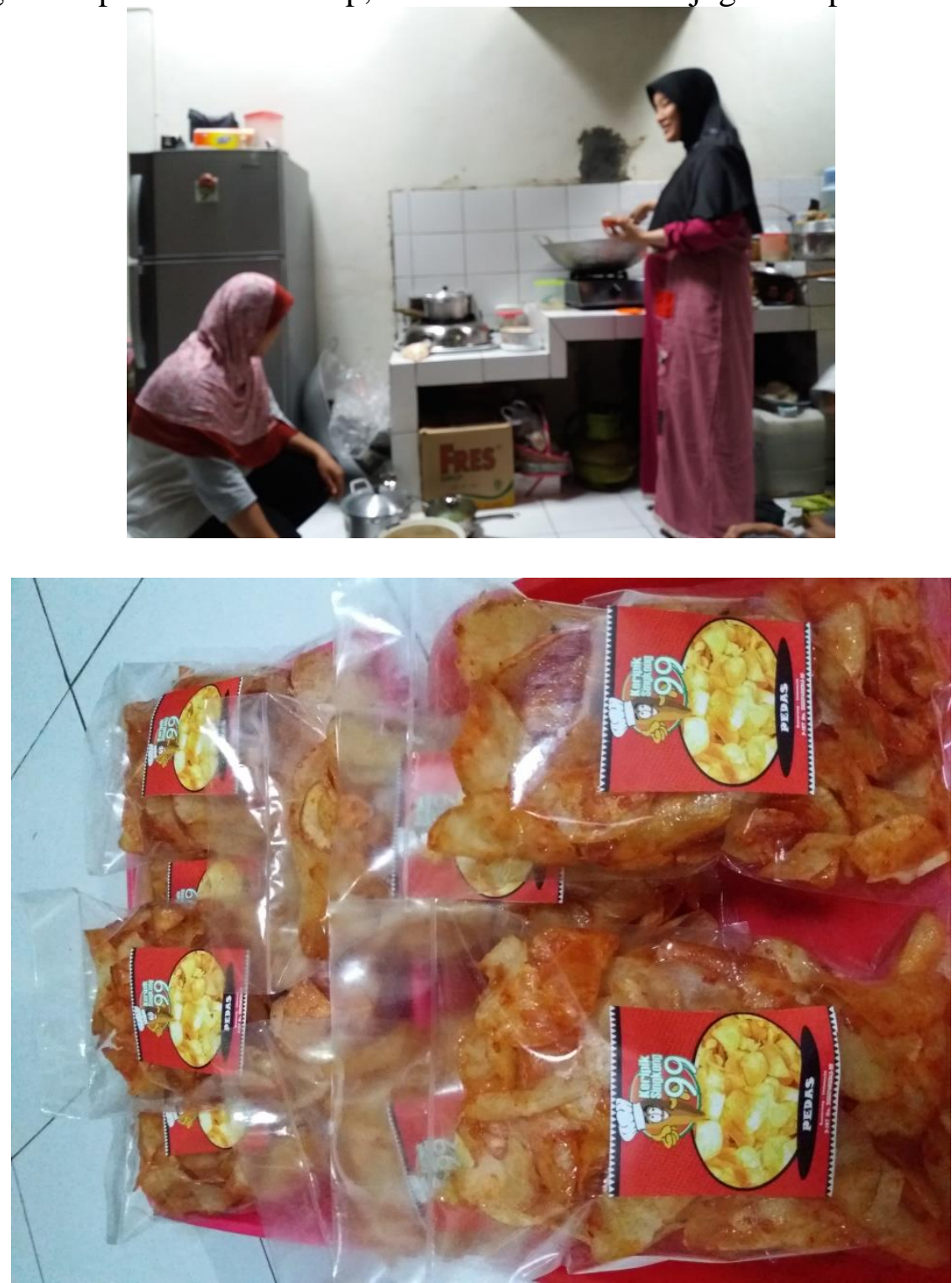

Gambar 2. Demontrasi Pembuatan Keripik Sesuai Resep 


\subsection{Pembuatan Exhaust dan Meja Ergonomis}

Solusi yang ruang pengolahan keripik singkong pedas tanpa cerobong asap dengan menambahkan exhaust, seperti pada gambar 3. Saat ini alur asap sudah tersirkulasi dengan baik dan udara di sekitar dapur tidak pengap dan lembab. Selain itu, untuk mengatasi keluhan pegal-pegal akibat mengaduk keripik yang tidak ergonomis dibuatkan meja yang tampak lebih rendah dibandingkan meja utama. Meja utama juga sudah mengalami renovasi sehingga dapat digunakan juga untuk pengolahan keripik.

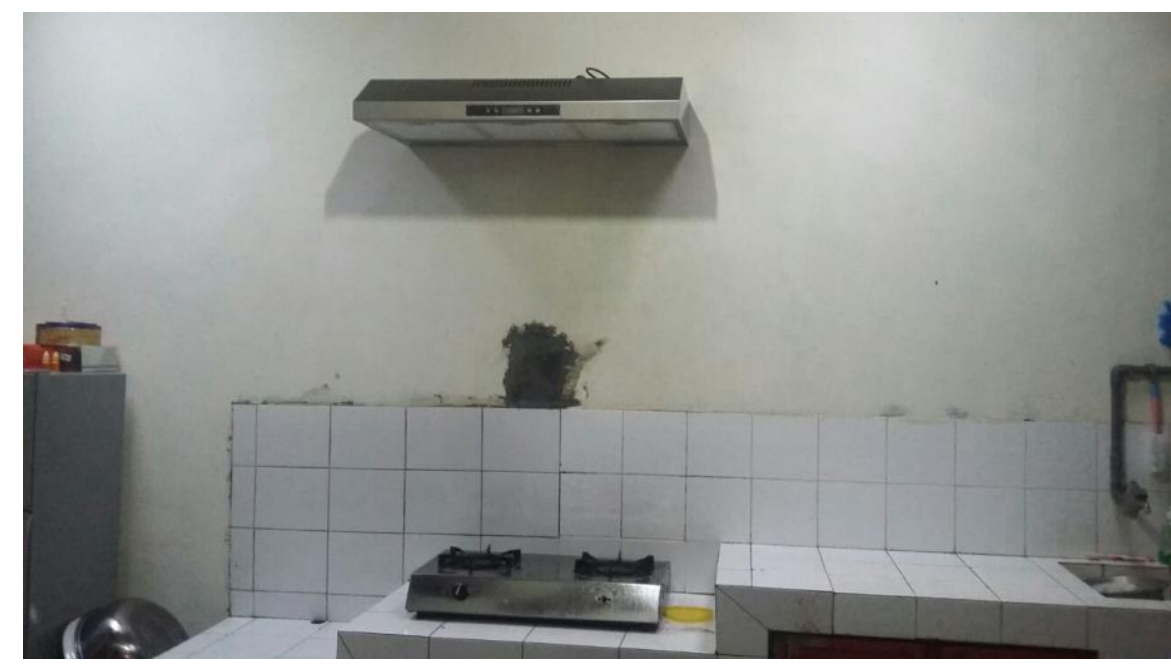

\section{Gambar 3. Pemasangan Exhaust dan Pembuatan Meja Ergonomis}

\section{SIMPULAN DAN SARAN}

Peningkatan praktik pengolahan singkong keripik pedas telah berjalan lancar dan sesuai target. Saran yang diberikan kepada kelompok industri keripik singkong pedas adalah perluasan pemasaran ke pasar yang lebih besar.

\section{UCAPAN TERIMAKASIH}

Terimakasih kami sampaikan kepada : 1) Pengelola Keripik Singkong Pedas 99, 2) LP2M Unnes. Kegiatan ini terlaksana atas pendanaan dari IbM Kemenristekdikti tahun 2016.

\section{DAFTAR PUSTAKA}

Anoraga Sudantoko, (2002). "Karakteristik Industri Kecil”. Jakarta :FE UI Bachtiar Hasan, (2003). "Manajemen Industri". Bandung: Pustaka Ramadhan Djaja I.M , (2003). "Pengaruh Jenis Tempat Pengelolaan Makanan terhadap Kontaminasi Bakteri Pada Makanan”.

Idham Alamsyah, (2005). " Jurnal Pembangunan Indonesia", Analisis nilai tambah dan pendapatan Usaha Industri Rumah Tangga Berbahan baku sagu dan ikan. 
Keputusan Menteri Kesehatan Republik Indonesia , Nomor

715/MENKES/SK/V/2003, tentang Persyaratan Hygiene Jasaboga. Jakarta: Depkes RI

Kuncoro, (2007). "Industri kecil dan UMKM". Jakarta: FE UI

Tulus Tambunan, (2002). "Usaha Kecil dan Menengah di Indonesia". Jakarta:

Salemba Empat

Undang-undang Republik Indonesia Nomor 9 Tahun 1995 Tentang Kriteria Industri Kecil 